\title{
Gråsten skolevæsens historie 1696-1920
}

\section{Af Jens Kongsted Lampe}

\section{Skolens grundlaggelse 1696}

De relativt få børn, der var i Gråsten, da den var en mindre funktionærbebyggelse, gik før $1696 \mathrm{i}$ Adsbøl skole; men efterhånden som bebyggelsen desuden blev et håndværker- og handelscentrum for omegnens landboere, kom der så mange familier med børn til slotsbyen, at der måtte indrettes en særlig skole for dem.

De første spor af et ordnet skolevæen i Gråsten stammer fra et godsregnskab fra 1699. I godsregnskabet forekommer der bilag for lønninger til skolemesteren, der fik 20 rdlr. af de betalende forældre samt 1 rdlr. 4 sk. for undervisning af 13 fattige børn årlig, mens han som organist fik en årlig løn på 10 rdlr., men da den første degn og skolemester blev kaldet 1696, må man regne dette år som skolens stiftelsesår. I 1699 var antallet af fattige elever 16 og i 1703: 27. I skolepenge skulle der svares 4 skilling pr. elev om måneden, dog betalte fattigkassen for børn af fattige forældre.'

Skolen blev oprettet af Friedrich Ahlefeldt, der var kongens statholder $\mathrm{i}$ den kongelige del af hertugdømmerne. Han var ejer af jorderne i og omkring Gråsten, hvor bønder og kådnere var livegne. Da godsherskabet næsten egenmægtigt havde indflydelse på kirke- og skolevæsenets ordning, er det naturligt at ofre nogle linjer på dette forhold.

\section{Slagten Ahlefeldt}

Ahlefeldterne nedstammer fra en indvandret holstensk uradel og havde tysk som hjemmesprog og tyske traditioner, ligesom de gik ind for tysk sprog og kultur og et tysk syn på en fyrstes ret og muligheder over for sin jord og de mennesker, der arbejdede på denne jord. Det var derfor en selvfølge for dem, at der skulle prædikes på tysk i slotskirken, som blev bygget sammen med slottet og - efter al sandsynlighed - indviet nytårsdag 1699. Det var også en selvfølge, at børnene på godsherrens område skulle undervises på tysk, så de senere kunne forstå den tyske konfirmandundervisning og prædikenerne i slotskirken, skønt tyskheden var et ubetydeligt mindretal i området. Det var i øvrigt en regel, at 
skolesproget rettede sig efter kirkesproget, og at man regnede skolesproget for tysk, hvor kirkesproget var tysk, selv om elevernes modersmål var det danske. Dog tillodes der senere, at der afholdtes dansk gudstjeneste hver tredje søndag.

Friedrich Ahlefeldt den Ældre og sønnerne Friedrich og Carl var kongens statholdere og Carl var den første, der i 1721 aflagde troskabseden til kong Frederik 4. på Gottorp, hvorved han lovede i påkommende tilfælde at vove gods og blod for den danske konge og erkendte, at denne var hertugdømmets eneste suveræne landsherre. Trods store indtægter fra sine godser blev Carl Ahlefeldts forhold elendige, og efter hans død i 1722 måtte alle hans sønderjyske besiddelser afhændes ved en tvangsauktion. Den nye ejer af Gråsten og omegn blev hertug Christian August 1. af Augustenborg, der nedstammede fra hertug Hans den Yngre, grundlæggeren af det lille sønderborgske fyrstendømme. Ved overtagelsen i 1725 omfattede købet Gråsten med slot og landbrugsbygninger, Fiskbæk og Kiding; men nogle år senere tilkøbtes yderligere jorder $\mathrm{i}$ omegnen. ${ }^{2}$ Christian August 1. var officer i den danske hær og blev general 1748. Endvidere var han amtmand og guvernør over Als 1732-54. Hertugen var gift med grevinde Frederikke Louise Danneskiold-Samsøe, og det hele var faktisk købt for hendes medgift. Med besiddelse af adeligt gods hørte visse standsprivilegier såsom uafhængighed af de almindelige danske myndigheder, bl.a. Tyske Kancelli og Rentekammeret. Han kunne selv give love, udskrive skatter, ja, endog slå mønt. Han havde domsmyndighed over fæstebønderne, dvs. politi-, hals- og håndsret, toldfrihed, jagt- og strandingsret m.m. Godsherren havde endvidere kaldsretten til at besætte embederne som slots- og sognepræst, degn, organist og skolemester. Gråsten hørte indtil 1850 til de exemte sogne, dvs. de stod ikke under tilsyn af den lokale provst $\mathrm{i}$ det pågældende provsti, men var direkte underordnet godsherren i verdslige spørgsmål og biskoppen (generalsuperintendenten) i Slesvig i kirke- og skolespørgsmål. Det siger sig selv, at godsets undersåtter havde store byrder at bære og var økonomisk, juridisk og moralsk afhængige af godsherren. I o. 125 år forblev Gråsten slot, der brændte 1757, under augustenborgerne, som benyttede slottet som sommerresidens. Efter genforeningen købtes det af den danske stat.

Gråsten var i hertugernes tid om ikke en egentlig flakke, så dog en anselig, flækkeagtig bebyggelse. Da Gråsten by skylder slottet og dets skiftende ejere sin eksistens, er der først befolkningsmæssig baggrund for en skole i 1690erne, og skønt flertallet af beboerne da talte og følte dansk, fik man altså, uden selv at have anmodet om det, tysk skole- 


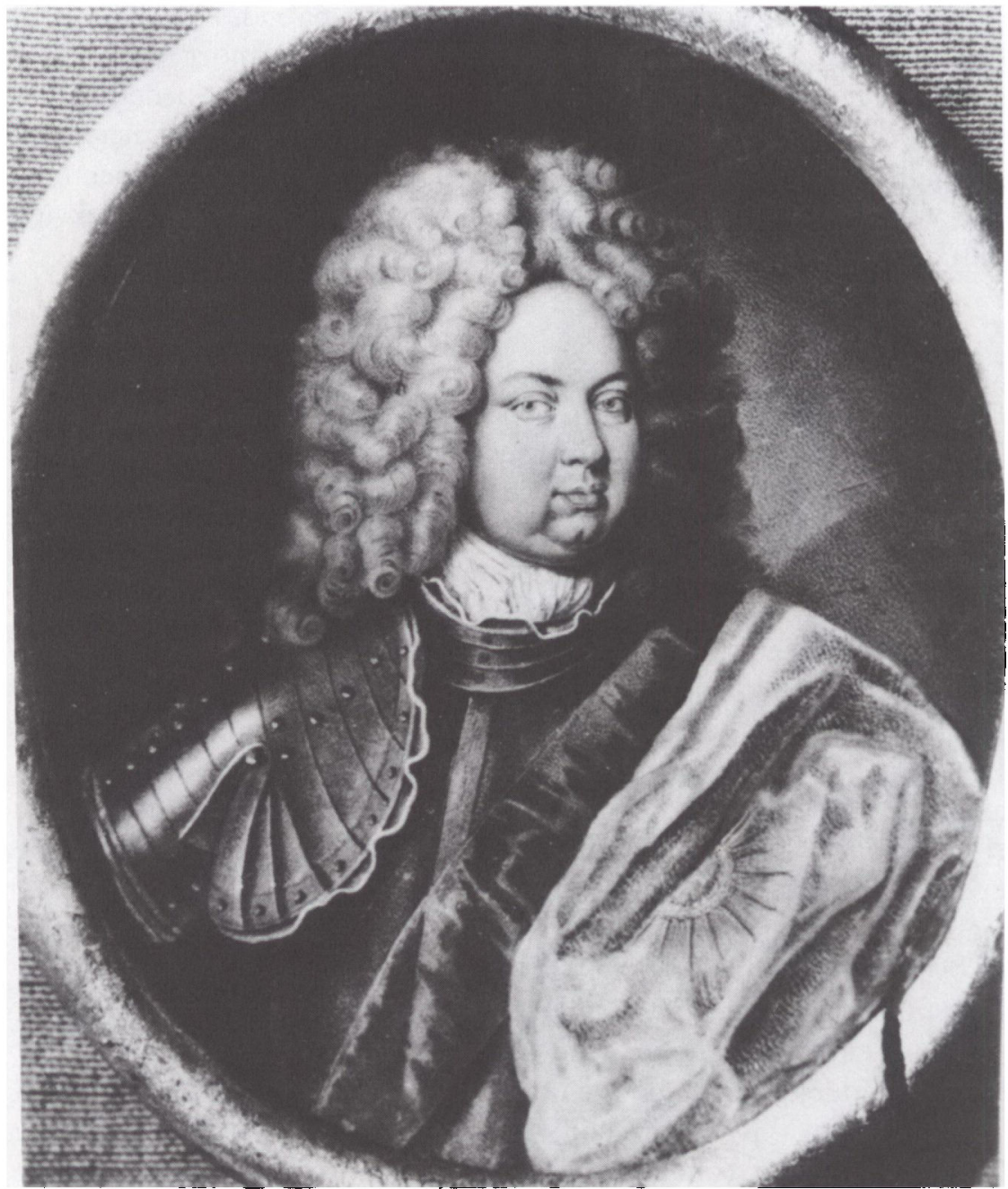

Lensgreve, Carl Ahlefeldt (1670-1722). Han arvede statholderembedet fra sin bror, Friedrich Ahlefeldt, og varetog det 1712-22. Da den hertugelige del af Sonderjylland $i$ 1721 blev indlemmet under den danske krone, var han den forste, der aflagde troskabseden til Frederik 4. (Historiske Samlinger for Sonderjylland)

sprog. Men da det var nytteløst at sætte sig op mod godsherren og myndighederne, måtte man affinde sig med forholdene, som de var og resignere. Livegenskabets ophævelse i 1805 var en fysisk og økonomisk befrielse, men med hensyn til kirke- og skolesproget skete der ingen ændringer. ${ }^{3}$ 
Det fremgår af godsets arkivalier, at det var påbudt skolemesteren, som også var degn og organist, at han hver sommermorgen fra kl. 78, om vinteren fra kl. 8-9 skulle holde en andagt eller bedetime for skolebørnene med læsning af skriftsteder, salmesang og bøn i nærværelse af alumnerne, som boede i fattighuset, der var bygget sammen med skolen. Om lørdagen skulle han gennemgå søndags-prædiken-teksten i kirken, katekisere over den og bede for sit herskab.

\section{De forste skolemestre}

Den første gråstenske degn og skolemester, der kendes ved navn, hed Hans Mortensen og var født i Åbenrå o. 1655. Efter sit giftermål i Oksenvad den 10. december 1681 med Maren Maria Jens Ravnsdatter af Bjerndrupgård i Stursbøl, kaldte han sig Martensen. Han begyndte som fæstebonde i Stursbøl, Oksenvad sogn, men blev i 1696 kaldet til degn, organist og skolemester i Gråsten. Når han omtales, skyldes det ikke, at man ved noget om hans kvalifikationer til at synge, spille og undervise, heller ikke hvorfor Ahlefeldt netop blev opmærksom på ham, men udelukkende fordi hans begavede datter, Maren Maria Martensen, senere gift Wulf og senest Ewald, blev digteren Johannes Ewalds (1743-1781) mormor. Ewald var bl.a. forfatter til Kong Christian stod ved højen mast, og denne sang er ofte sunget i Gråsten, især efter 1935, da Gråsten blev indrettet til sommerbolig for daværende kronprins Frederik og kronprinsesse Ingrid. Maria Martensen var pietistisk vakt og gjorde sig allerede kendt som 25 -årig ved at udgive en oversættelse af Chr. Scrivers prædikener "Sjæleskat« fra tysk i 1711. Hun talte djærvt og skrev fyndigt tysk og dansk, men helst det sidste.

Hvor længe faderen var degn og skolemester i Gråsten vides ikke, men han døde i hvert fald ikke i byen. I 1711 fik han Gabriel Jennerich som medhjælper. Denne giftede sig med Hans Martensens datter Anna Catharina og forfremmedes i 1721 til degn, organist og skolemester efter sin svigerfar. ${ }^{4}$ Foruden slotsfogden, godsinspektøren, en husfoged, en gartner, en skovfoged og en til slotskirken knyttet præst boede der i Gråsten en hel del hertugelige betjente og underordnet personale, samt en del håndværkere, handlende og fiskere. Skolen søgtes også af børn fra de tilstødende bebyggelser: Nalmadebro, Alnor og Trappen samt Fiskenæs. Foruden en beskeden pengeløn fik de første degne og skoleholdere i Gråsten naturalier som flæsk, kød og smør samt $2 \frac{1}{2}$ td. rug, 5 tdr. byg, $1 \mathrm{td}$. boghvede, 2 tdr. land til græsning for en ko eller et får og som vinterfoder 2 læs halm. Endvidere havde de fribolig i 
skolelængen. Dertil kom så kirkelønnen på 10 rdlr. årlig af kirkekassen for alle søn- og helligdage. For at holde opsyn med de fattige børn skulle de yderligere have $20 \mathrm{sk}$. af fattighjælpekassen, så længe det var muligt. Forsømte børnene skolen, blev der ikke betalt skolepenge. Så måtte skolemesteren selv tage tabet. Først i 1709 fik han et fast beløb for 20 fattige børn i alle 52 uger, nemlig 21 rdlr. 32 skilling.

Skoleeleverne havde fri til alle kirkelige højtider, men ingen egentlig sommerferie. Dette begreb kender man først fra en gottorpsk skoleforordning fra 1733. Her tales der om "visse dages ferier (dvs. fridage) i den store hede. « Fattigkassen betalte de nødvendige skolebøger til børn af fattige forældre, men i det store og hele fik de kun én katekismus hver, desuden pen og blæk. Andre bøger forekom som klassesæt, således at eleverne måtte se sammen to og to. Det gjaldt f.eks. Bibel og salmebog. Af regnskabet fremgår, at børnene undervistes i religion, tysk, regning og skrivning. Først 1706 fik skolen en jernovn. Man lejede den hos isenkræmmer Matthias Lysholm i Flensborg, men allerede i 1709 dristede man sig til at købe den.

Degnen Gabriel Jennerich omtales som død i 1747. Hans enke fik et halvt "nådsensår«, dvs. hun fik lov til at blive boende i mandens tjenestebolig $\frac{1}{2}$ år samt et mindre beløb $\mathrm{i}$ penge. Jennerich afløstes af Christian Jacobsen fra Havetoft på Angel som degn, organist og skolemester. Han kunne dansk, og nu blev det ordnet således, at børnene fra Gråsten så vidt muligt undervistes på tysk, mens børnene fra landdistrikterne undervistes på dansk, omend et noget ufuldkomment dansk. Den daværende danske dialekt på Angel var beslægtet med dialekten på Sundeved og afveg ligesom den noget fra rigsdansk.

I 1730 kritiserede hertug Christian August undervisningen i Adsbøl skole og truede den daværende degn med at sætte ham på halv løn, hvis han ikke bedrede sig, og skulle advarslen ikke hjælpe, ville degnen blive afskediget og børnene fra Adsbøl skole ført til Gråsten. Truslen blev dog ikke gennemført, men har nok virket efter hensigten.

I 1758 blev skolemesterlønnen i Gråsten hævet til 30 rdlr. foruden de skolepenge, forældrene skulle betale. Men det voldte altid kvaler med at få dem indkasseret. Samme år døde Chr. Jacobsen og enken fik et helt nådsensår.

Efterfølgeren blev Friedrich Tücksen fra Hatsted ved Husum. Han varetog degne- og skolemesterembedet indtil 1779 og underviste kun mådeligt $\mathrm{i}$ dansk. Hans efterfølger hed Johannes Andresen og virkede tillige som organist ved slotskirken. Andresen var født i Sønderborg og 
kunne dansk. Da han havde hertugens bevågenhed, blev han hertugelig sekretær og kasserer i København 1787-1804 og endte som hertugens hofråd i Gråsten.

Af en skoleplan fra 20. april 1768 udstedt af hertug Friedrich Christian fremgår det, at den daglige skolegang begynder $\mathrm{kl} .7 \mathrm{om}$ sommeren og kl. 8 om vinteren og varer til kl. 4 om eftermiddagen bortset fra onsdag og lørdag, da man har fri. Vanskelige børn skal formanes og deres forseelser noteres i protokollen. Ved legemlig revselse skal der vises mådehold, hvorledes det så må være blevet fortolket. Hertugen var skolens patron, dvs. beskytter og tilsynsførende, og kun han alene kunne give børnene fri fra skole. Gyldig grund til forsømmelse er sygdom og nødvendigt arbejde ved pløje- og høsttid. Skolepengene sættes til til 1-1 $\frac{1}{2}$ sk. pr. uge. Desuden skulle der - som før - betales brændselspenge af hvert barn fra Mikkelsdag den 29. september til påske af hvert frit barn. Ordet "frit « må her tolkes, som at skolen også besøgtes af børn af livegne, og disse er uden tvivl blevet undervist på dansk.

\section{Nye skolebygninger}

I 1779 udarbejdedes en plan til en ny og større skolebygning, som skulle placeres i Skolegade. Skolen blev indviet i 1783, netop som en økonomisk krise satte ind og forårsagede en snigende inflation, så man havde været heldig med at få en mønsterskole, set ud fra den tids forhold, $i$ rette tid.

Skolen bestod af et stort klasseværelse og en bolig for skolemesteren. Ikke langt fra skolen lå fattighuset. I 1783 gik der 52 børn af fattige forældre gratis i skole, og Johannes Andresen anskaffede dette år 2 tyske og 2 danske katekismer, 1 tysk og 1 dansk salmebog på fattigkassens regning. Skolestuen var på fire fag og tjenesteboligen på syv fag. Disse to bygninger samt brændselsskur og halvtag kostede dengang 707 rdlr. Uheldigvis brandte bygningerne 1808, men blev nyopført samme sted (Skolegade 7 og 9). Mens byggeriet stod på, undervistes børnene i den af prinsesserne oprettede spindeskole. Denne skole var indstiftet i 1787 til fattige børns oplæring i en nyttig syssel. Her modtog de nødtørftig undervisning i de elementære fag, og desuden fik de lært at spinde, væve, strikke eller sy, hvis de var piger, mens drengene fik lejlighed til at arbejde $i$ et linnedvæveri. Spindeskolen lå i Skolegade. Det lå $\mathrm{i}$ tidens ånd, at børn blev anset for at være "små voksne«. De måtte ikke fristes af for megen fritid, for »lediggang er djævlens hovedpude«; men de skulle tidligt lære at arbejde, være nyttige og 


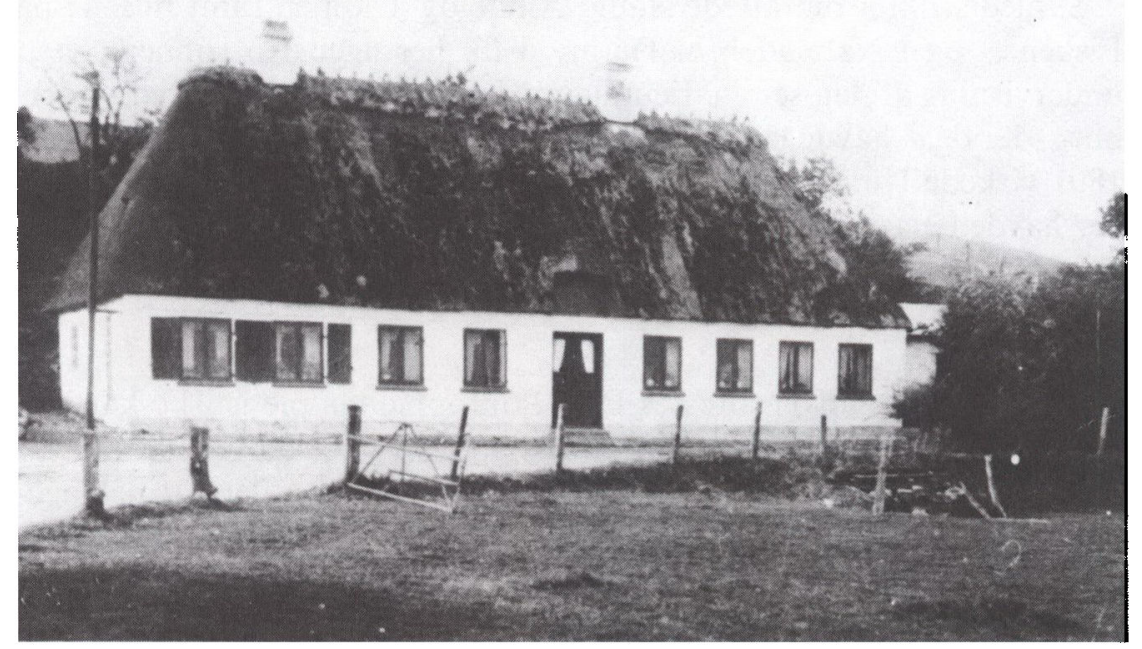

Den gamle skole i Gråsten. (Historiske Samlinger for Sonderjylland)

pligtopfyldende. Skolen gik kun i 4-5 år og blev derefter omdannet til en industriskole for unge over konfirmationsalderen. ${ }^{5}$ Industriskolen lededes af spindemester Erik Hagenberg, født i Borgå (Porvoo) i Finland 1758, hvor han havde lært både spinderi og væveri. Han kom til Gråsten 1791 og giftede sig med en pige fra Gråsten, Anna Christine Johansen. Hagenberg døde i Gråsten 1824.

I 1791 havde Johannes Andresen fået en hjælpelærer, Detlev Löck, fra Ølsby på Angel. Angelboerne blev i stor udstrækning anvendt som lærere $\mathrm{i}$ hertugens områder, fordi langt de fleste af dem kunne både tysk og dansk. Löck kom året efter på seminariet i Kiel (oprettet 1781) delvis på hertugens regning. Herfra fik han lærereksamen i 1794 og blev året efter Johs. Andresens afløser som degn, organist og førstelærer, den første seminarieuddannede i Gråsten. Löck var på seminariet blevet optaget af rationalismens tanker og var metodisk og pædagogisk veludrustet. Han udarbejdede i 1797 et detaljeret forslag til en bedre klassedeling og undervisningsplan og ønskede f.eks. indført geometri og landmåling, da kundskab herom var gavnlig, hvis det senere skulle falde $\mathrm{i}$ elevernes lod at være behjælpelig med en udskiftning. Bortset fra, at Löck gik ind for, at alle børn skulle undervises på tysk fra starten af, betød forslaget i mange henseender en pædagogisk forbedring, og 
et nyt skoleregulativ af 16 . december 1803 kom ham til undsætning med hensyn til gennemførelse af forbedringer.

Skoledistriktet omfattede stadig Alnor og Trappen samt husene på Fiskenæs og i Nalmadebro. Derimod fik hertugens to sønner privat undervisning af den seminarieuddannede Hans Hinrichsen fra Sønderborg, der også havde lærereksamen fra seminariet i Kiel. Men fra 17971801 virkede Hinrichsen som andenlærer ved byskolen. Det var Löck, der havde bevæget hertugen til at dele skolen i en hovedklasse (ældste) og en elementærklasse (yngste). ${ }^{6}$

\section{Nye lareboger}

Ifølge skoleregulativet afløstes Erik Pontoppidans pietistiske katekismusforklaring fra 1752 af dr. Christian von Stöckens »Die lautere Milch des heiligen Catechismi«, Ratzeburg, 1672, og det var beklageligt, at et værk af den mand, som i 1745 var den første, der gjorde opmærksom på det danske sprogs sørgelige stilling i Sønderjylland, og som hævdede, at det tyske sprog måtte være til skade for tilegnelsen af evangeliets sandhed, nu skulle trænges tilbage. ${ }^{7}$ Desuden skulle Hübners bibelhistorie læses. ${ }^{8}$ Hver formiddag og eftermiddag skulle der regnes og skrives, og de større børn skulle lære brevskrivning efter diktat samt brevlæsning. Disciplinen eller tugten skulle stadig ske med besindighed og mådehold, for skolen var »kein ängstliches Zuchthaus zum Schrecken der Kinder.« I henhold til regulativet indførtes også fast lærerløn, nemlig 150 rdlr. om året, således at hertugen af fattigkassen skulle betale $1 / 3$ heraf, mens resten fordeltes på husejere og lejere med henholdsvis 1 rdlr. 12 sk. og 16 skilling hver. Lærerne havde pligt til at undervise alle børn i skrivning, mens det indtil da havde kostet ekstra at lære dette. I skoleåret 1802-03 lærte godt halvdelen af eleverne at skrive. I 1825 nævnes det, at 149 børn går i Gråsten skole, fordelt med 70 elever i ældste og 79 i yngste klasse. Den 2-klassede skole omfattede børn fra Gråsten, Nalmadebro, Fiskenæs, Trappen, Alnor og dele af Ladegårdskov. I 1840 gik der kun 130 elever i de to klasser; men to år senere var børnetallet oppe på 151 elever, og førstelærer Löck fremsatte nu ønske om, at der oprettedes 3 klasser. Ønsket blev efterkommet og der indrettedes et klasseværelse i det såkaldte hospital (her $\mathrm{i}$ betydningen forsørgelsesanstalt for uarbejdsdygtige og gamle), senere Skolegade 13, som blev nedrevet i $1970 .^{9}$

Detlev Löck søgte på grund af svaghed sin afsked i 1837 og fik tildelt en hjælpelærer fra 1837-45. Da biskop C. F. Callisen, Slesvig, visiterede skolen i 1839 skrev han i visitationsprotokollen: "Löck har 
tjent Gråsten skole i 42 år med stor troskab og velsignelsesrig virkning.« Det nævnes naturligvis ikke, at han også nidkært havde medvirket til tyskhedens fremme.

\section{Frederik 6. magteslos}

Efter indstilling fra sine rådgivere havde kong Frederik 6. allerede i 1807 besluttet, at samtlige regeringskollegiers forordninger, patenter og befalinger skulle affattes og udstedes både på dansk og tysk i de egne af hertugdømmerne, hvor dansk sprog benyttedes; men adskillige kollegier og overretten på Gottorp tog ikke den kgl. beslutning til efterretning, skønt kongen var enevældig, og embedsmændene havde aflagt ed til ham. Ved kgl. reskript af 15 . december 1810 blev det ligeledes besluttet, at det tyske skolesprog i Gråsten skulle afskaffes. Det tyske kancelli i København rettede sig ikke derefter, og skolesproget forblev tysk med de få undtagelser, der er nævnt i det foregående. Frederik 6. havde villet gøre noget alvorligt for danskheden i Sønderjylland; men han magtede ikke at gennembryde den usynlige mur, hans tyske embedsmænd rejste mod hans vilje. ${ }^{10}$

At det overvældende flertal af Gråsten sogns indbyggere, som ved folketallingen i 1840 talte 840 personer, heraf 442 i selve byen, talte en dansk dialekt havde hertug Christian August (1798-1869) ingen forståelse for, skønt hans hustru og hjemmesprog var dansk, og de materielle værdier af bøger, malerier, møbler og sølvsager, hertugparret efterlod sig, for hovedpartens vedkommende var dansk kulturgods. Hertugen var $i$ al stilhed begyndt at modarbejde sin konge og de kongelige kollegier, og selv om han var en åndsaristokrat, der så med stor skepsis på de demokratiske rørelser, blev han efterhånden Uwe Jens Lornsens talsmand og slesvig-holstenernes fører, også i kampen mod modersmålet. Dette vidste $H$. C. Andersen næppe meget om, da han den 18. og 19. november 1845 skrev eventyret om $"$ Den lille pige med svovlstikkerne« på Gråsten slot, hvor han var gæst. Men det blev også sidste gang, han besøgte hertugfamilien. ${ }^{11}$

I 1845 fik førstelæreren 600 mark i løn, deraf 150 mark fra den hertugelige kasse og 19.200 stk. tørv. Som degn og organist fik han 90 mark fast samt 135 mark i accidenser, dvs. ydelser ved dåb, vielser og udsyngninger ved begravelser. Desuden havde han brugsretten til $1 \mathrm{td}$. land af god bonitet. Elementærlæreren fik 150 mark i årlig løn, og den hertugelige kasse betalte førstelæreren 60 mark for elementærlærerens kost og logi - såvel som 2.400 tørv til opvarmning af hans kammer, samt 1 pund tællelys til oplysning af hans kammer. Lønningerne var 


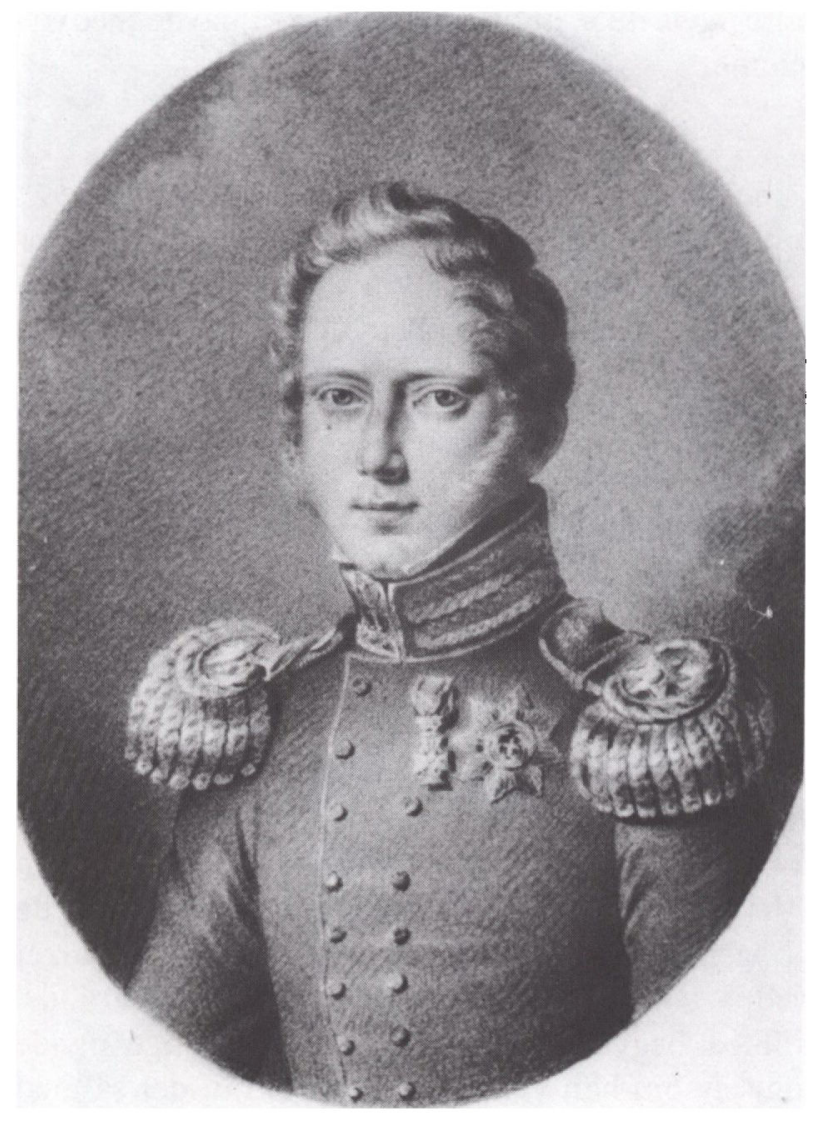

Christian August 2. (1798-1869), hertug af Augustenborg, blev af godsejerne valgt til medlem af den slesvigske standerforsamling 1835. Han havde stor indflydelse pd skolevasenet i Gråsten, men var ikke en ven af den frie debat. Han dode som en ensom, bitter og dybt skuffet mand i Primkenau 1869.

(Historiske Samlinger for Sanderjylland)

relativt gode, men betingelserne var naturligvis fuld loyalitet mod hertugen, som kunne kalde og afskedige efter forgodtbefindende. I 1845 ansattes Jens Christian Jarck som førstelærer, degn og organist i Gråsten. Han havde taget lærereksamen i sin hjemby, Tønder, 1834, og kom fra en stilling i Nibøl, Tønder sønderamt. Han var hertugens lydige redskab, hvilket han viste ved flere lejligheder, men også en pligtopfyldende og dygtig lærer med en omfattende viden og evner til at formidle den videre til sine elever.

\section{Hertugen forbereder et opgor}

Efter at kong Christian 8. havde udstedt sit »åbne brev« i 1846, optrådte hertugen som en åben, hårdnakket og uforsonlig fjende af 
Danmark, og det trak op til et opgør, ja, begge parter kunne faktisk tale om »eine Erhebung «, en rejsning, et opbrud. Vi fik den slesvigholstenske bevægelse, Treårskrigen $1848-50$ med sejre og nederlag og senere slesvig-holstenernes store skuffelser over ikke at have nået deres mål og hertugens flugt fra Als og udvandring til godset Primkenau i Schlesien. I Gråsten afskaffedes tysk prædiken, da embedet i efteråret 1850 nybesattes, idet den daværende slesvig-holstensk-sindede slotspræst Jürgen Brag var flygtet over hals og hoved efter slaget ved Isted den 25. juli, og samme år indgav den nye sognepræst i Adsbøl-Gråsten, Nic. E. Engel, forslag om, at dansk, da det nu var udelukkende kirkesprog i Gråsten, også måtte indføres i skolen, eftersom det var et almindeligt ønske i sognet, når undtoges enkelte, navnlig bemidlede familier.

Som tidsfrist foreslog Engel begyndelsen af det nye skoleår den 1 . april 1851. Det tyske sprog var i sin tid indført som en aldeles exceptionel indretning til fordel for et mindretal, nemlig godsherskabets tyske embedsmænd og tjenerskab, uden at befolkningen var blevet spurgt. Ved reskript fra regeringskommissæren af 30 . december 1850 bestemtes det, efter sognepræstens forslag, at undervisningen i Gråsten skole skulle meddeles på dansk fra og med den 1. april 1851. Palmesøndag samme år konfirmeredes det første hold konfirmander på dansk $\mathrm{i}$ slotskirken. Pastor Engel skriver i en indberetning 1855, at det slet ikke voldte vanskeligheder for børnene at følge danskundervisningen. De kunne dansk i forvejen og viljen var god. ${ }^{12}$

Førstelærer Jens Chr. Jarck fik af sine nye foresatte at vide, at han kunne forblive i sit embede, så længe han viste troskab og hengivenhed for konge og fædreland og var villig til at undervise på dansk. Hvis ikke, ville man foreslå ham at søge et andet embede, hvor hans gode tyske sprogkundskaber ville komme ham til gode. Jarck var noget betænkelig ved at skulle undervise på dansk med det grundlag, han havde fået på seminariet og sendte efter nogen betænkningstid sin afskedsansøgning. Han var en kortere periode justitiarius i Gråsten, derefter lærer ved en tysk privatskole i Haderslev og døde som førstelærer, organist og degn i Zarpen ved Lübeck i 1878. Derimod blev Jarcks hjælpelærer, J. H. Lausen, afskediget for illoyalitet, hvilket han heller ikke protesterede imod.

Som ny degn, organist og førstelærer ansattes efter sommerferien 1851 Christopher Emil Olsen, der havde eksamen som privatist fra Jonstrup seminarium ved København og havde virket nogle år på Sjælland. 


\section{A.D.Jørgensens skoleår}

Gråstens største danske søn, A. D. Jørgensen (1840-97), historiker, rigsarkivar og den, som gav tilskyndelsen til udgivelsen af Sønderjyske Årbøger, gik i skole i Gråsten i tiden mellem de to slesvigske krige. Hans far, farvermester M. A. Jürgensen, der var født og opvokset i det overvejende tysktalende Flensborg, og moderen, der var fra Åbenrå, havde til 1848 tysk hussprog, men talte sønderjysk med tjenestefolkene, naboerne og kunderne. Men da faderen hørte om oprøret i Kiel og Rendsborg, forbød han straks tysk tale $\mathrm{i}$ hjemmet og blev egnens danske tillidsmand, så sønnen siden kunne skrive: »Jeg kan dristig sige, at Sundeveds danskhed $\mathrm{i}$ disse forvirrede år havde sine rødder $\mathrm{i}$ vor stue.«

Om sin skoletid i Gråsten 1846-53 skriver Adolf Ditlev Jørgensen: "I skolen lærte vi mange samfundsforhold at kende, som kun den blandede almueskole giver lejlighed til. Flere af mine kammerater tjente på landet eller for til søs om sommeren. Andre sankede brænde eller var på skovarbejde om vinteren. - Skolen har altid haft stor betydning for mig. Henved seks år gammel kom jeg $\mathrm{i} » d e n$ lille skole«, hvor vi lærte begyndelsesgrundene. Det var et usselt rum, overfyldt af børn, og jeg var ofte forknyt, når en eller anden havde fået lyst til at yppe klammeri med mig. Jeg var lille og bleg og lignede min mor. Min tyske tale ærgrede adskillige mere stridbare naturer, ikke af nationale grunde, men fordi det var fint. Jeg husker endnu, at det voldte mig vanskeligheder at finde de danske ord, når jeg talte med kammeraterne. Mærkeligt nok slog vort jyske mål i de få år, til jeg forlod hjemmet, alligevel så stærkt rod hos mig, at det indtil den dag i dag er det sprog, som falder mig lettest på tungen.

Der var i denne klasse en del ældre børn, som undervistes på dansk og derfor aldrig kom over i »den store skole«. En af disse tog sig af mig og straffede hårdt enhver forgribelse på mig. Jeg husker, at han engang tog en dreng $i$ benene og dunkede ham med hovedet op imod det lave loft. - Der foretoges hver påske efter konfirmationen en opflytning fra den lille til den store skole, og det var min første udmærkelse, at jeg flyttedes uden for tiden, midt i skoleåret og alene. Det var mandag den 10. oktober 1848. Datoen har jeg husket indtil nu. (Skrevet 1896). Det vakte opsigt, og jeg husker tydeligt, hvorledes den tyske degn (J. C. Jarck) i frikvarteret fra den høje stentrappe til »den store skole« kaldte på mig og sagde, at jeg skulle hente mine sager og komme til ham. Da jeg kom med tavlen under armen og bøger og blækæske $\mathrm{i}$ hånden, blev der stille på pladsen og drengene 
Rigsarkivar

A.D. Jorgensen

(1840-97) var elev $i$

Gråsten skole 1846-

53. Han larte bade

tysk og dansk og kla-

rede sig udmarket.

(Historiske Samling-

er for Sonderjyl-

land)

sagde halvhøjt, hvor jeg kom frem: „Oddolf ska' ind i den stor' skol'.»

Jeg havde et meget let nemme, og da min aldste broder, Asmus, konfirmeredes palmesøndag 1853, sad jeg så højt oppe, at jeg ville blive øverst på drengesiden, når konfirmanderne forlod skolen. Men samtidig ville min undervisning i virkeligheden have været afsluttet, skønt jeg endnu havde tre år til konfirmationen, thi den danske degn, der efter krigen havde afløst den tyske, stod langt tilbage for denne $i$ kundskaber og forringede i høj grad skolens hele stilling. Fader bestemte sig derfor til at sende mig til Flensborg, hvor en realskole var blevet oprettet $\mathrm{i}$ forbindelse med latinskolen, og ligesom denne med dobbelt undervisningssprog, « skriver A. D. Jørgensen. ${ }^{13}$ 
Det eneste, en del forældre i Gråsten havde imod den nye degn og førstelærer, C. E. Olsen, var, at han ikke talte korrekt tysk; men ved visitatserne findes der ingen negativ kritik af hans undervisning eller disciplin. A. D. Jørgensen, som $\mathrm{i}$ flere år kun havde læst tyske bøger og kun hørt Gråsten-dansk, har nok undret sig over, at en førstelærer ikke kunne tale korrekt tysk. Han fortæller, at han en dag på loftet fandt en gammel dansk bog, "Bondepraktika«, og ved at stave sig frem i den til sin store overraskelse mærkede, at han kunne læse dansk. Hans dialekt var altså dansk. Siden blev han meget optaget af Blichers noveller og Ingemanns historiske romaner om Valdemar Sejr og hans heltegerninger, om Niels Ebbesen og hans stolte dåd, om Svend Trøst, Karl af Rise og prins Otto af Danmark og hans sørgelige skæbne. Disse bøger lånte A. D. Jørgensen hos førstelærer Olsen, der var bibliotekar i Lånebogsamlingen for Gråsten og Omegn, en af de 143 bogsamlinger, som »Komiteen for Oprettelsen af danske Folkebiblioteker i Slesvig« mellem krigene fik etableret. Den havde til huse på apoteket.

I 1859 var elevantallet i Gråsten 80 i yngste klasse og 75 i ældste. I juli 1863 indførtes et nyt skoleregulativ, ifølge hvilket skolekommissionen skulle bestå af præsten som født formand og skoleinspektør samt 5 valgte medlemmer fra skoledistriktet. Børnene skulle indmeldes, når de var fyldt 6 år, og blive i skolen, til de var konfirmeret. Onsdag og lørdag eftermiddage havde man stadig fri. Der var juleferie fra 23.12.31.1., påskeferie fra tirsdag før Skærtorsdag til onsdag efter påske, pinseferie fra fredag før pinse til onsdag efter, sommerferie i tre uger, så vidt muligt $\mathrm{i}$ høsttiden. Desuden var der fridage på kongens fødselsdag, fastelavns-mandag, to dage ved Broager marked: forår og efterår og dagen før eksamen. Endelig var der en halv nøddeplukkedag, en halv slædedag og en halv skøjtedag. ${ }^{14}$

\section{Under fremmedherredømmet}

I begyndelsen af februar 1864 drog den danske hær på tilbagetoget gennem Gråstens hovedgade, og umiddelbart efter fulgte de preussiske og østrigske tropper. Gråsten var nu blevet en by med 988 indbyggere, bestående af 239 familier og havde tre lager, et apotek og to sparekasser: en for selve Gråsten og en for Sundeved. I byen boede herredsfogeden og husfogeden for Lundtoft herred. Til Gråsten regnedes to huse fra Toft, o. halvdelen af husene i Alnor, to kådnersteder af Ladegård, fiskerlejet Nalmadebro, ladepladsen Stengerodde og Gråsten gods.

Den 7. februar tog den danske hær sit hovedkvarter i Gråsten, og 
trods det hårde vintervejr spredtes meddelelsen om hærens tilbagetog ad sne- og isglatte veje rundt omkring og vakte nedslåethed $i$ alle dansksindede kredse. Allerede den 29. februar 1864 afsattes de fastansatte lærere i Gråsten, og der indførtes atter tysk skole- og kirkesprog. Dette blev dog først helt effektivt fra påske 1866, og overgangen var ret lempelig, selv om det ikke gik uden protester. Den 27 . juli indsendtes en petition af skolekommissionen til den preussiske civilregering i Flensborg om, at det danske sprog måtte bibeholdes i Gråsten og omegn, da befolkningen ikke havde udtrykt onske om at få tysk skolesprog og var overvejende dansktalende. Petitionen var underskrevet af H. Clausen Gad, købmand Jes Detlefsen, købmand Peter Marcussen, Hans Hansen og husfoged Wegge. Sidstnæunte blev i 1865 afskediget fra sit embede af preusserne og udvist. Blikkenslager Johann Chr. Kückelhahn (1824-71), der var det femte medlem af skolekommissionen, afgav en særindstilling og tog initiativet til en tysk petition. Civilregeringen svarede den 5. august 1864, at indbyggerne i Gråsten ikke forstår det danske sprog, "da sie von Geburt und Erziehung deutsch sind. « Så vidste de det. - Det var lykkedes Kückelhahn at samle 77 underskrifter, fortrinsvis fra andre indvandrede tyskere med bøn om indførelse af det tyske sprog i skolen. Kückelhahn ville dog ikke bestride, at dansk var flertallets sprog; men han var af den mening, at det ville være ønskeligt, om børnene fik noget mere undervisning $i$ tysk. ${ }^{15}$

Civilregeringen traf $\mathrm{i}$ januar 1865 den foreløbige beslutning - efter indstilling fra provstiets kirkevisitatorium - at dansk og tysk skulle ligestilles som kirkesprog i Gråsten, og at skolesproget i den nuværende underklasse skulle være dansk og i hovedklassen tysk. Førstelærer og degn Olsen fik at vide, at hvis han ikke var det tyske sprog mægtig, måtte han søge sig en stilling andetsteds. Han afgav erklæring om, at han ikke var det tyske sprog så mægtig, at han kunne anvende det som undervisningssprog. Olsen sendte derefter en ansøgning om afsked med pension den 16. februar 1865; men den nyudnævnte pastor Eduard Rönnau i Adsbøl-Gråsten syntes ikke, der var nogen som helst grund til at bevilge ham pension, når han ikke var kvalificeret til sit embede. Olsen blev boende i Gråsten fra 1865-69 som leder og bogholder i den danske sparekasse for Sundeved og bibliotekar for den danske bogsamling. Derefter blev han ansat som kordegn, klokker og graver ved Vor Frelsers kirke i Horsens.

Den danske skolekommission opløstes. Købmand Jes Detlefsen forlod Gråsten i 1865 og afløstes af den tyske rebslager W. Reinholdt. I 
stedet for den udviste husfoged Wegge indtrådte den tyske dr. med. Brieger, og købmand Peter Marcussen, der havde beholdt sin danske statsborgerret $\mathrm{i}$ henhold til freden $\mathrm{i}$ Wien, blev udvist, fordi hustruen, født i Holsten, uden hans samtykke og ledsagelse havde deltaget $i$ en udflugt til Vestjylland. Selv havde han ikke i nogen som helst henseende gjort sig ufordelagtigt bemærket. Han afløstes af den tyske justitsråd J. Grotrian. Skolekommissionens protokol førtes fra den 10. juni 1865 på tysk. Den nye tyske sognepræst, J. G. C. Wulff, holdt sig helt uden for de nationale spændinger. ${ }^{16}$

Som ny førstelærer, degn og organist ansattes den 2. maj 1865 Daniel Nannsen (lærereks. fra Tønder 1854). Han var født i Gråsten som søn af en tilfyttet politibetjent og havde hidtil virket som lærer i Holsten. Ved den danske klasse (yngste) ansattes Jacob Peter Frederiksen fra Bøglund i Farensted sogn på Angel. Han havde ikke taget lærereksamen, men gået et år på Skårup seminarium ved Svendborg og var faktisk ukvalificeret, men skønnedes altså god nok til at undervise $\mathrm{i}$ dansk. I årene 1859-67 havde C. H. Staugaard været lærer i 3. klasse. Staugaard begyndte allerede som lærer i Gråsten 1833, men da der blev oprettet en særlig skole i Ladegårdskov i 1843, som afløste en biskole fra 1781, forflyttedes han hertil, for så atter at vende tilbage til Gråsten fra 1. november 1859-31. december 1867. Derefter fastansattes han som enelærer i Ladegårdskov, hvor han virkede til sin død i 1875 . Det blev pålagt lærerne i Gråsten at undervise to timer om ugen i den ældste klasse i geometri og begyndelsesgrundene i matematik, som det havde været tilfældet før 1848. Endvidere blev det påbudt at indføre et "gymnastikapparat«, hvad det så kan have været.

En forudsætning for ansættelse i lærerembeder var, at man var villig til at aflægge eden til den preussiske konge (kejser). Når en lærer blev kaldet til et embede, måtte han over for kredsskoleinspektøren med tre fingre i vejret sværge følgende ed: Jeg N.N. sværger ved Gud den almægtige og alvidende, at jeg vil være underdanig, tro og lydig over for Hans Kongelige Majestæt af Preussen, min allernådigste herre, og at jeg efter bedste viden og samvittighed vil opfylde alle til mit embede hørende pligter, og at jeg samvittighedsfuldt vil rette mig efter grundloven, så sandt hjælpe mig Gud for Jesu Kristi skyld, Amen.«

I 1868 undervistes 99 børn på tysk i ældste klasse og 76 på dansk, i alt 175 elever. En lille tysk privatskole havde 6 elever. Man kunne nu i byen spore de tilflyttedes tilstedeværelse - tyske lærere, en postagent, en civilstandsembedsmand (Standesamt), en amtsforstander, en kommuneforstander, toldere, postbude, politibetjent, gendarm og andre 
med blanke knapper og kasket, måske også "Schnurrbart« og "Schmiss«, dvs. ar efter kårdefægtning eller endda dueller. Værre var det, at unge danske udvandrede til kongeriget eller til oversøiske lande, især USA.

Tre skolekommissionsmedlemmer, nemlig F. W. Bruun, C. Christensen og J. Tegge sendte i 1869 en protest til regeringen i Slesvig i anledning af et pålæg om at anskaffe et vægkort over Det Nordtyske Forbund, som var dannet i 1866, til skolen. De udtrykker den mening, at skolen er tilstrækkeligt udrustet med geografiske vægkort og meddeler ved samme lejlighed, at de har en formodning om, at det tidspunkt må være forestående, da Prag-fredens $\S 5$ vil blive bragt til udførelse, hvilket utvivlsomt vil bevirke en forandring af ovenstående vægkort.

Baggrunden var nok, at danskheden i Gråsten efter en fortvivlelsens og sløvhedens periode fra nederlaget i 1864 til rigsdagsvalget den 12 . februar 1867 havde oplevet en ændring og et opsving med nyt håb, da rigsdagsvalget gav det overraskende resultat, at der afgaves 213 danske stemmer i Gråsten og kun 90 tyske.

Svaret fra regeringen var naturligvis et prompte afslag, og de tre skolekommissionsmedlemmer blev skarpt belært om, at de ikke skulle bryde sig om Tysklands grænser. I 1874 gik der 78 elever i den tyske skoleafdeling og 85 i den danske. ${ }^{17}$

I 1870 afløstes Nicolau Boysens »Første Læsebog for Skolerne paa Landet« af »Vaterländisches Lesebuch für die evang. Volksschule Norddeutschlands« og en »Preussischer Kinderfreund «, som »Flensborg Avis« citerede lange uddrag af, bl.a. følgende (oversat): "Vort hele folk fra Elben til Kongeåen, fra Østersøen til Vesterhavet er tysk, tysk i hver åre og i hver blodsdråbe, tysk i sine dyder, men også tysk i sine svagheder, tro og tappert, med jernsener og stålnerver, men også tysk i sindighed og tålmod, derfor længe tavst og stumt og kun kraftigt i passiv modstand." - Efter offentliggørelsen af disse citater inddroges læsebøgerne i Gråsten igen, og der indførtes i stedet for en tysk læsebog, som knap var så udfordrende og uvederhæftig. ${ }^{18}$

Fra 1873-75 var Claus Jensen Svane (1850-1908) fra Vonsbæk førstelærer og degn i Gråsten. Han var i det stille dansksindet, men trivedes ikke under forholdene i den nationalt blandede by og søgte til Svenstrup på Als, hvor han døde.

Endnu i 1875 var Gråsten delt i en tysk afdeling med 72 elever og en dansk med 107 elever, men i 1878 kom der en skolelov, efter hvilken de fleste timer $\mathrm{i}$ begge afdelinger skulle foregå på tysk, og i $1888 \mathrm{kom}$ endelig den tredje skolelov, der indførte tysk som undervisningssprog 
i alle fag med undtagelse af et par timer $i$ religion, der kunne ske på dansk, hvis et flertal af forældrene ønskede det - og - vel at mærke turde ansøge derom. I praksis betød det, at de tyske timers tal på skoleskemaet nu blev fordoblet fra 6 til 12 timer. Samtidig krævedes, at lærerne skulle bruge tysk også ved tiltale på legepladsen og drage omsorg for at børnene benyttede det tyske sprog indbyrdes ved samtale og leg.

Da biskop Bertel P. Godt visiterede Gråsten skole i 1880, fandt han, at børnenes tysk var mangelfuldt og fuldt af danismer. Myndighederne søgte at bøde på visse læreres mangelfulde tyskkundskaber ved at sende dem på et 6-ugers kursus i tysk på seminariet i Segeberg.

Efterhånden blev det umuliggjort at oprette danske privatskoler og lade børn under 14 år undervise på kongerigske skoler. Børnene $\mathrm{i}$ Gråsten skulle nu lære preussisk og brandenburgsk historie i stedet for hjemstavnens, de skulle synge tyske fædrelandssange og salmer, fejre kejserens fødselsdag og mindedagen for slaget ved Sedan samt følge tyske skikke i skolen. Den danske afdeling var endelig blevet ophævet i 1879. Samme år ansattes lærer Jes Peter Holm, som udnævntes til førstelærer ved skolen i 1884 og virkede i embedet til 1920.

I de danske hjem vaktes mere og mere forståelsen for den truende fare, der lå i ligegyldigheden, resignationen, accepten af tingenes tilstand, og forældrene bødede efter evne og formåen på den usynlige skade, der skete i skolen. På forskellig vis tilskyndedes hjemmene til at opretholde det danske sprog. Flensborg Avis, der på den tid var grænseegnens mest udbredte og respekterede blad, udgav en hjemmestavebog i 9.000 ekspl. og en sangbog for børn, der udsendtes med alle danske blade i i alt 12.000 ekspl. Matthias Andresen (1858-1916) i Åbenrå begyndte fra oktober 1890 at udsende et Illustreret Børneblad for Nordslesvig for at skaffe børnene god læsning på modersmålet, og Sprogforeningen begyndte at uddele boggaver til børn i $1880 .^{19}$

I 1875 var der en kreds af tyske forældre i Gråsten, som mente, at børnene lærte for lidt $\mathrm{i}$ kommuneskolen og gerne ville have dem forberedt til højere undervisning i mellem- og realskolen. De oprettede en tysk privatskole med lærerinde Maria Louise Brieger som lærerinde. Skolen havde først lokale i Fredensgade, siden i Elleysgade. Frøken Brieger døde i 1893, og fire år efter blev privatskolen 2-klasset. I ældste klasse var der 10 piger, hvoraf den yngste var 9 år, de ældste 13-14 år. I yngste klasse var der 9 elever, nemlig tre drenge og seks piger. Eldste klasse undervistes af frk. Pfitzmann. Det ugentlige timetal var 31, nemlig $4 \mathrm{i}$ religion, $5 \mathrm{i}$ tysk, $4 \mathrm{i}$ regning, $6 \mathrm{i}$ realfag (dvs. historie, 
geografi og naturhistorie), 2 i tegning, 2 i håndarbejde, 4 i fransk og $4 \mathrm{i}$ engelsk, men ingen timer $\mathrm{i}$ dansk. Hver lektion var på 50 minutter, og der betaltes skolepenge.

I yngste klasse underviste frk. Heinsen, som var dimitteret fra Augustenborg lærerindeseminarium 1897. Hun har bemærket, at alle børn kunne tale dansk. Elevtallet var i 1902: 13 drenge og 9 piger og havde da en rektor Weber som leder. I 1904, da der var 17 drenge og 13 piger, nævnes en cand. teol. Otto Johns som leder, ikke rektor. Skolens elevtal nåede aldrig over 40 elever, men ser ud til at have haft sit højdepunkt i 1906 med 23 drenge og 16 piger, og Otto Johns nævnes stadig som leder. Som medhjælpere havde han frk. Kiebitsch til håndarbejde og frøknerne Schott og Margrethe Leopold. Sidstnæunte blev i 1914 gift med læge, dr. med. Nis P. Nielsen (1868-1937), Gråsten; hun virkede som lærerinde 1905-14. Der findes stadig en tysk privatskole i Gråsten, »Fördeschule«. ${ }^{20}$

\section{Ny bygning 1899}

Efterhånden som elevantallet $\mathrm{i}$ kommuneskolen voksede, blev lokaliteterne i skolen for små, og i 1895 udarbejdedes planen for en ny skolebygning (den ældste del af den nuværende skole). Denne indviedes den 28. juli 1899 med de sædvanlige festtaler. Den nye skole havde 4 klasseværelser, et lærerværelse, bolig til 2 ugifte lærere og en pedelbolig i kælderen. Til førstelæreren (rektor) købte man villa "Clara«, som lå ved siden af skolen. Denne var bolig for skolelederen indtil 1958 og lå der, hvor senere fysiklokalet blev indrettet. Elevtallet var i 1895: 257 og skolen havde da 4 lærerkræfter.

Grunden til skolen var købt af proprietær Jørgen Peter Hansen for 2.000 mark. Til opførelsen optoges et byggelån på 18.000 mark til 6 \%, som skulle afvikles på 30 år. Lånet måtte dog senere forhøjes væsentligt til trods for, at prislejet da var ret stabilt. Projektet blev udarbejdet af arkitekt Prahl, Flensborg. - Som medlemmer af skolekommissionen var i 1898 sognepræst Steffen, H. Thomsen, F. Lenschau, Madsen, Witt og bogbinder Bock. - I 1904 var elevtallet 128 drenge og 126 piger, i alt 254 elever. Den daglige undervisningstid var om vinteren fra kl. 8,30-11,30 og fra kl. 1-4. Om sommeren var der lektioner fra kl. 8-12 og fra 1,30-3,30. Skolens bibliotek bestod af 420 bind, alle bøger på tysk. Undervisningen i håndarbejde varetoges af frk. Asmussen. I 1901 var 119 børn angrebet af mæslinger, så skolen var lukket fra 27. november-8. januar 1902. Året efter måtte børnehaven og skolen lukke på grund af en kighoste-epidemi, der varede fire uger. 
En skrivelse af 12. juni 1912 fra kredsskoleinspektør Claus Schacht, Åbenrå, viser noget om tyskernes ihærdige kamp imod det danske sprog. I skrivelsen hedder det: »Hvis forældre sender en ansøgning på dansk om deres børns deltagelse i dansk religionsundervisning, vil den bestemt blive afvist."

I tiden 1696-1920 har der været ansat knap 70 lærere og lærerinder, som man sagde tidligere. De unge lærere, der så godt som alle kom sydfra, især fra Angel, det øvrige Sydslesvig og Holsten, skiftede med få års mellemrum. De kom med den forudsætning, at de skulle undervise tysksprogede børn »in der Nordmark « og måtte ofte gøre kedelige erfaringer, som slet ikke svarede til deres forventninger. En af dem, J. W. Schätzel, fik ligefrem et nervesammenbrud og måtte søge orlov $\mathrm{i}$ tre måneder. Så snart de unge lærere havde muligheder for at få embeder syd for Skelbækken og Kruså eller stillinger, der var bedre aflønnet, flyttede de dog helst til et sted, hvor de var velkomne og kunne få kontakt med den omboende befolkning. ${ }^{2 !}$

I 1900 lod firmaet Max Opitz i Berlin på foranledning af hertug Ernst Günther (1863-1921) en arkitekt fra Hannover, Hugo Mossner, udarbejde et projekt, hvis intentioner var at styrke erhvervslivet og tyskheden i Gråsten og omegn. Projektet gik ud på, at der skulle bygges en arbejderkoloni for 140 familier i Gråsten. Disse arbejdere skulle beskæftiges dels ved en cementfabrik og dels ved et nyt teglværk ved Sildekulen, hvor der skulle indrettes en $6 \mathrm{~m}$ dyb havn. Her skulle bygges 12 huse til 36 familier. Projektet omfattede også en ny skole til o. 200 børn, delt i 4 klasser, hvor der skulle ansættes 3 lærere og en lærerinde. Det var meningen, at byggeriet skulle igangsættes foråret 1901. Af grunde, som arkivalierne ikke oplyser, antagelig finansieringsvanskeligheder, blev projektet i 1903 reduceret. Cementfabrikken blev opgivet. ${ }^{22}$ Schleswigsche Grenzpost skriver den 6. januar 1903, at på initiativ af hertug Ernst Günther, hertug Friedrichs søn, er der oprettet en lervarefabrik i Gråsten. Der skal desuden anlægges en gødningsfabrik på Pelzerhof. Teglværket kom $\mathrm{i}$ gang ved skoven Overstjernen i 1908 og købtes i 1922 af H. Clausen, Hillerød. Pelzerhof blev solgt til firmaet Anthon \& Söhne i Flensborg, der indrettede en maskinfabrik i bygningen, senere overtaget af A/s Gråsten Maskinfabrik, Slotsbakken 25 . De øvrige dele af projektet ses aldrig at være blevet realiseret.

Den augustenborgske hertugslægt uddøde på mandssiden i 1931 med den i England bosatte hertug Albert. 
De skolepligtige børn fra Alnor fik i 1913 deres egen skole og dermed kortere skolevej.

\section{Krig og genforening}

Den første verdenskrig 1914-18 fik naturligvis alvorlig indvirkning på livet $\mathrm{i}$ skolen her som andre steder. Seks lærere blev indkaldt til tysk felttjeneste, hvoraf de tre faldt og én blev taget til fange og blev sekretær og hjælpepræst for de sønderjyske fanger $i$ den franske fangelejr Aurillac i provinsen Auvergne. Hans navn var Hans FuglsangDamgaard, og han endte sit virke som biskop over Københavns stift 1934-60. Mange af skolebørnenes fædre eller ældre brødre blev indkaldt til krigstjeneste, og mødrene stod alene med opdragelsen og andre byrder. Skolen måtte lukkes i længere eller kortere perioder på grund af brændselsmangel, nødvendige indsamlinger, af forskellig art, vanskeligheder med at skaffe egnede vikarer og sygdomsperioder. Man styrkede den tysk-patriotiske indstilling ved at lade børnene fejre dem helt uvedkommende mindedage, f.eks. 50-årsdagen for den store preussiskøstrigske sejr ved Dybbøl, som fejredes den 18. april 1914, fire sejrsfester i 1915, det sejrrige søslag i Nordsøen og Bukarests fald i 1916 foruden de sædvanlige festdage, f.eks. kejserens fødselsdag den 27. januar, indtil kejser Wilhelm 2. den 9. november 1918 måtte vige for revolutionsbølgen og flygte til Holland, hvor han døde 1941.

Trods en ikke ubetydelig indvandring sydfra af tjenestemænd, akademikere og håndværkere og trods et økonomisk-moralsk tryk, som et hertugeligt og senere et preussisk formynderskab kan pålægge en befolkning i meget jævne kår, holdt danskheden sig med beundringsværdig standhaftighed, og kun fă var svage og svigtede. I national henseende bevarede Gråsten under hele fremmedherredømmet sit danske flertal ved valgene. I 1912 var der 152 danske og 143 tyske stemmer. Ved afstemningen den 10. februar 1920: 561 danske og 407 tyske, eller $58 \%$ danske og uden tilrejsende: $67 \%$. Ved folketingsvalget i 1920 faldt der 212 dansk-borgerlige, 91 socialdemokratiske og 91 tyske stemmer. Med genforeningen i 1920 var det endelig slut med påtvungne skoleordninger og en helt uheldig sprogordning. Såvel danskere som hjemmetyskere kunne nu udøve deres selvbestemmelsesret i fuld frihed i henhold til grundlovens bestemmelser $\S 83$ og loven om frie eller private skoler.

J. P. Holm, som i 1920 fyldte 65 år, søgte sin afsked som skoleleder (rektor) i Gråsten og blev den 1. april 1920 afløst af Hans Christian 
Hansen (1882-1971) fra Herning, som havde lærereksamen fra Ranum 1908. Endvidere ansattes Ejnar C. Hansen, dim. Jonstrup 1918, Jens Andersen, dim. Jelling 1920, Carl Agnhof, dim. KFUMs sem. København 1917, Asta Agnhof, dim. Odense 1921, Laurits Andersen, dim. Jelling 1902 og Matthias Hansen, dim. Tønder 1890.

I 1920 udvidedes skolen med fire klassevarelser til otte efter tegninger af arkitekt Stender samt en række faciliteter, og den fik nyt undervisningsmateriale. Samme år oprettedes den første klasse af den tilsluttede Gråsten kommunale mellem- og realskole. Der afholdtes mellemskoleeksamen første gang i 1923 og realeksamen i 1924.

\section{HENVISNINGER OG NOTER}

1. M. H. Nielsen: Træk vedr. Fattig-, Skole- og Kirkevæsen i Gråsten 1699-1769 i Sdj. Årb. 3 rk., 1933, s. 101-127. - Landsarkivet i Åbenrå: Augustenborgske Distrikter. Rep. C IV. Afl. fra Kiel 1936, Acta C IV. De hertugelige augustenborgske distrikter nr. $31,140,144,145,312$ og 423-28.

2. H. P. Clausen og Jørgen Paulsen: Augustenborgerne. Slægt, Slotte, Skæbne, Sønderborg, 1980. - Jørgen Paulsen: Augustenborg, Kbhvn. 1981.

3. A. D. Jørgensen: Graastens ældre Historie i Sdj. Arb. 1889, s. 1-43. - Johan Hvidtfeldt: Augustenborgerne og de gråstenske bønder i Sdj. Mdsskr. 1950, s. 1528.

4. Landsarkivet i Åbenrå: Afl. Kiel 1936, Acta C IV, De hertugelige augustenborgske distrikter, nr. 144: Degne og skole i Gråsten 1711-1853. - Vilh. Andersen: Illustreret dansk Litteraturhistorie, Kbhvn. 1934, bd. II, s. 370. - Louis Bobé: Johannes Ewald, 1943.

5. Landsarkivet Åbenrå: Af. Kiel 1936 nr. 145: Industriskole i Gråsten. - SchleswigHolst. Provinzialberichte, 1792.

6. Som nr. 4.

7. Erik Pontoppidan (1698-1764) f. i Århus, havde været diakon i Nordborg og sognepræst i Havnbjerg på Als, siden biskop i Bergen og prokansler ved universitetet i København. Han var den første, der gjorde dansk offentlighed opmarksom på det danske sprogs undertrykkelse i Senderjylland.

8. Johann Hübner (1668-1731), tysk skolemand og lærebogsforfatter. Han havde også udarbejdet en geografi og regnebog. - Nicolay Boysen var sogneprast i Nybøl 17941829. Hans danske læsebog udkom første gang i Sønderborg 1822.

9. L. A. Åbenrå: Sønderborg Provstearkiv. Skolesager fra Adsbøl og Gråsten 17681878.

10. H. Rosendal: Trak af Danskhedens Historie i Sønderjylland, Kbhvn. 1919, bd. I, s. 82-87. L. A. Åbenrå: 70. Gråsten og Adsbøl præstearkiv, Fb 4 1768-1918.

11. J. P. Trap: Danmark, 5. udg. 1967, Åbenrå-Sønderborg amter, s. 966.

12. Som nr. 9. - L. A. Åbenrå: Ábenrå provstearkiv, 1850-1920. Sager vedr. de enkelte sogne. Adsbøl-Gråsten. - Visitationsprotokoller for Adsbøl-Gråsten. - Sønderborg provstearkiv: Visitationsprotokoller for Adsbøl-Gråsten. - Holger Hjelholt: Den 
danske Sprogordning og det danske Sprogstyre i Slesvig mellem Krigene 1850-1864, Kbhvn., 1923, s. 26-30. - Sønderborg provstearkiv, nr. 1330: Skolesager 1850-64.

13. A. D. Jørgensen: En redegørelse for min udvikling og mit forfatterskab, 1901.

14. L. A. Åbenrå: Visitationsprotokol for Adsbøl-Gråsten 1851-63. - Abenrå provstearkiv 1861-1921: Sager vedr. de enkelte sogne: Adsbøl-Gråsten. - Gråsten skolekommissions protokol 1864-80. - Johs. Ahlmann: Allerlei aus Gravenstein, 1928.

15. Gråsten skolekommissions protokol 1864-69.

16. Samme. - Sønderborg provstearkiv. Skolesager 1864-78.

17. Samme. - 70 Gråsten-Adsbøl præstearkiv, bd. 3, 1738-1906, kirke- og skolesprog 1824-65. - A. D. Jørgensen; Graastens ældre Historie i Sdj. Årb. 1889, s. 1-43.

18. Artikel i "Dagbladet«, Kbhvn. for 5. juli 1870, s. 2 sp. 1-2. Om N. Boysen, se note 9.

19. L. A. Åbenrå: Visitationsprotokol for Adsbøl-Gråsten. - Ảbenrå provstearkiv: 1861-1920: Sager vedr. Adsbøl-Gråsten. Gråsten skolekommissions protokol 186980.

20. L. A. Slesvig: Abt. 309, nr. 13/27 - Gråsten. L. A. Åbenrå: Åbenrå provstearkiv 1861-1920: sager vedr. Adsbøl-Gråsten.

21. Samme.

22. Se nr. 20. - L. A. Gottorp, Slesvig: Abt. 309 nr. 212 59. Endvidere er benyttet: J. H. Frees: Af Graastens Historie indtil Aaret 1835. Særtryk af "Flensborg Avis«. Historisches Taschenbuch für Prediger und Schullehrer und andere Freunde und -Beförderer des Kirchen- und Schulwesens in der Herzogthümer Schleswig und Holstein auf das Jahr 1803, Slesvig, 1803. - H. N. A. Jensen: Kirchliche Statistik des Herzogthums Schleswig, bd. 4, Flensborg, 1842, s. 1447-1451. - P. Paulsen: Versuch einer Schulstatistik des Herzogthums Schleswig, 1845. - M. Mørk og C. L. Nielsen: Kirkelig Statistik over Slesvig Stift, bd. 2, s. 119-123. - Dansk Skolestat, I-IV, Kbhvn. 1933-34. - Jens Lampe m.fl. Tønder Seminarie-Stat, Tønder, 1963, L. S. Ravn: Lærerne i Nordslesvig ca. 1814-1920, Ábenrå 1978, I og II, samt flere stater og biografiske værker. Kirkebøger og folketællinger fra Gråsten, L. A. Ábenrå. 
